\title{
Novel 3,3-disubstituted oxindole derivatives. Synthesis and evaluation of the anti-proliferative activity
}

Michael S. Christodoulou ${ }^{\mathrm{a}}$, Ferdinando Nicoletti $^{\mathrm{b}}$, Katia Mangano ${ }^{\mathrm{b}}$, Maria Assunta Chiacchio ${ }^{\mathrm{c}}$, Giorgio Facchetti $^{\mathrm{a}}$, Isabella Rimoldi ${ }^{\mathrm{a}}$, Egle M. Beccalli ${ }^{\mathrm{a}, ~}{ }^{*}$ and Sabrina Giofrè ${ }^{\mathrm{a}}$

aDISFARM, Sezione di Chimica Generale e Organica “A. Marchesini” Università degli Studi di Milano, via Venezian 21, 20133 Milano, Italy.

${ }^{b}$ University of Catania, BIOMETEC, Via Santa Sofia 97, 95123, Catania, Italy

${ }^{c}$ University of Catania, Dipartimento di Scienze del Farmaco, Viale Andrea Doria, 6, 95125 Catania, Italy

\section{ABSTRACT}

3,3-Disubstituted oxindole derivatives bearing a nitrogen atom at the C-3 position have been synthesized starting from 3-alkyl oxindole through a metal free pathway. These derivatives have been tested in five human tumor cell lines (PC3, MCF7, SW620, MiaPaca2 and A375) and on primary cells (PBMCs) from healthy donors providing compound $\mathbf{6 d}$ showing a strong anticancer effect in all cancer lines on the low micromolar range.

Keywords:

3,3-disubstituted oxindole

isocyanate

iminophosphorane

Anti-proliferative activity

Human cancer cell lines

The oxindole is a scaffold of a large family of natural and unnatural compounds endowed with biological activities. ${ }^{1-5}$ Among them 3,3-disubstituted oxindole derivatives are recognized as valuable compounds for drug discovery, ${ }^{6-9}$ and also as key intermediates for the synthesis of many kinds of drug candidates. ${ }^{7,10-15}$ In particular, oxindoles bearing an amino group at the 3-position are belonging to a variety of pharmacological active molecules, such as the gastrin/CCK-B receptor antagonist AG-041R (1), ${ }^{16}$ the vasopressin VIb receptor antagonist SSR-149415 (2) ${ }^{17-20}$ and the HIV protease inhibitors 3 (Figure 1). ${ }^{21}$
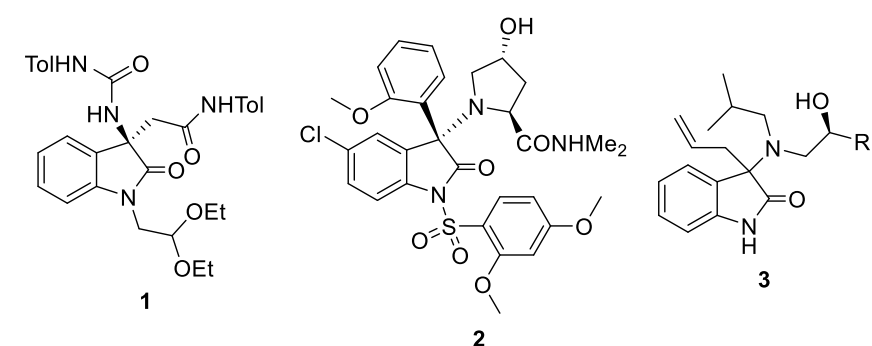

Figure 1. 3,3-Disubstituted oxindole derivatives. 
Due to the interest of this class of oxindole derivatives, a lot of attention has been devoted to the development of new synthetic strategies to access to oxindoles bearing a nitrogen atom at the C-3 position. ${ }^{22-}$ ${ }^{24}$ In this field, significant advances have been achieved in the organocatalytic ${ }^{25-29}$ or metal-catalyzed ${ }^{30,31} \alpha-$ amination of 2-oxindoles.

Herein, based on our experience in the functionalization of oxindole derivatives ${ }^{32-34}$ and in the transformation of heterocyclic rings, ${ }^{35-38}$ we describe the synthesis of a new class of 3,3-disubstituted oxindoles, bearing a nitrogen substituent in C-3 exploiting a metal free pathway. Continuing our researches in the synthesis of anticancer compounds, ${ }^{39-49}$ the aim was to investigate the potential biological activity of the target compounds on different cancer cell lines.

Starting from 3-alkyl oxindoles, the 3-bromo derivatives $\mathbf{4}$ were obtained in quantitative yield by reaction with bromine in dichloromethane at r.t., following a procedure previously described by our group. ${ }^{37}$ Subsequently, compounds 4 were reacted with sodium azide to form the 3-azido derivatives $\mathbf{5}$, which were then treated with triphenylphosphine to provide the stable iminophosphoranes 6 (Scheme 1). The compounds 6a and $\mathbf{6 c}$ were quantitatively deprotected at the position 1 under basic conditions to give the corresponding derivatives $\mathbf{6 f}$ and $\mathbf{6 g}$ (Scheme 1). The synthesis of the target isocyanates 7 was achieved by reacting the iminophosphoranes 6 with $\mathrm{CO}_{2}$, in a close vessel, at $50{ }^{\circ} \mathrm{C}$ in THF. Compounds $7 \mathbf{a}, 7 \mathbf{b}, 7 \mathbf{d}$ and $7 \mathbf{e}$ were obtained in moderate to good yields (55-70 \%). Low solubility of compounds $\mathbf{6 f}$ and $\mathbf{6} \mathbf{g}$ in THF, drove us to use as solvents DMF for $\mathbf{6} \mathbf{f}$ and $\mathrm{MeOH}$ for $\mathbf{6 g}$. In these solvents, the reaction of $\mathbf{6} \mathbf{f}$ and $\mathbf{6 g}$ with $\mathrm{CO}_{2}$ provided the amine 8f and the amide 9 correspondingly (Scheme 1). The iminophosphorane $\mathbf{6 c}$ resulted unreactive under the standard conditions.

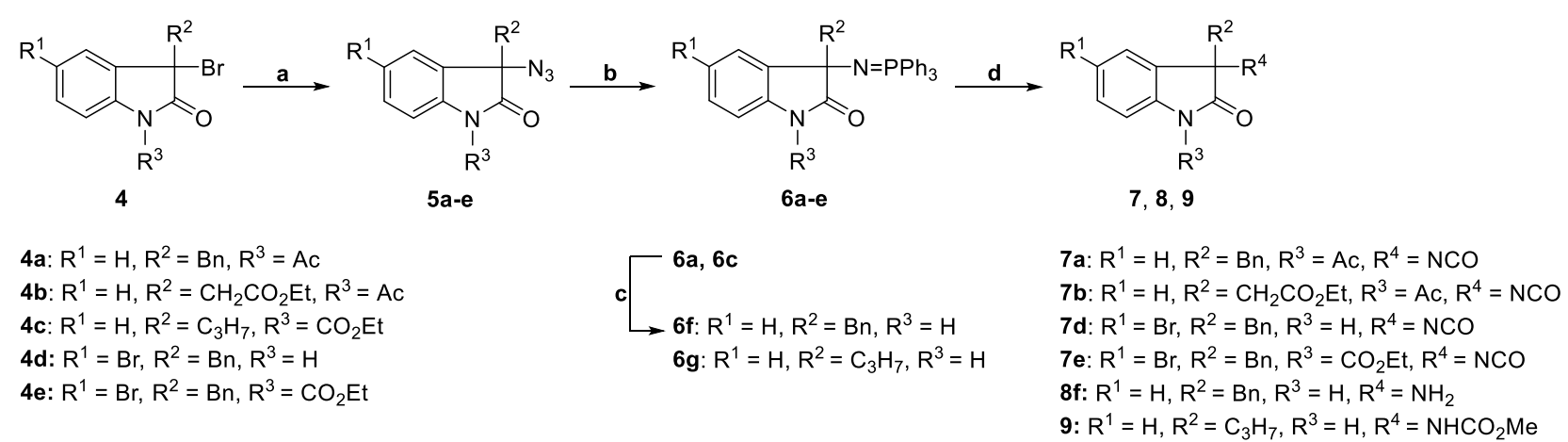

Scheme 1. Reagents and conditions: (a) $\mathrm{NaN}_{3}$, tetrahexylammonium iodide, $\mathrm{DCM} / \mathrm{H}_{2} \mathrm{O}$, r.t., overnight; (b) $\mathrm{PPh}$, DEE, r.t., 3 h; (c) $\mathrm{NaOH}$, EtOH, r.t., overnight; (d) $\mathrm{CO}_{2}$, THF (DMF for $\mathbf{6 f}$ and $\mathrm{MeOH}$ for $\mathbf{6 g}$ ), $50{ }^{\circ} \mathrm{C}\left(90{ }^{\circ} \mathrm{C}\right.$ for $\mathbf{6 f}$ ), overnight. 
Treatment of the azide $\mathbf{5 d}$ with a solution of $\mathrm{HBr}$ in $\mathrm{AcOH}$, allowed the formation of the amine $\mathbf{8 d}$, which was subsequently reacted with benzoyl chloride and diethyl chlorophosphate to provide compounds $\mathbf{1 0 a}$ and 10b respectively (Scheme 2).

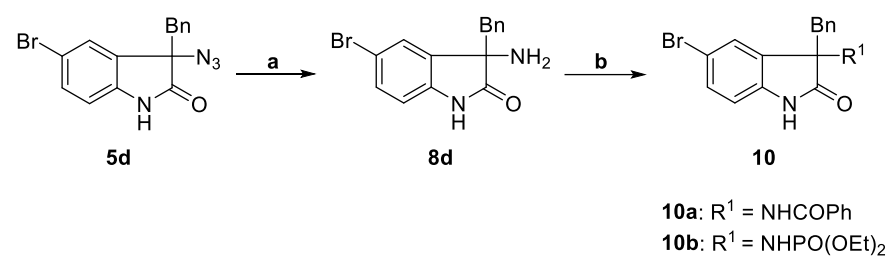

Scheme 2. Reagents and conditions: (a) $\mathrm{HBr}$ in $\mathrm{AcOH}, \mathrm{AcOH}, 0{ }^{\circ} \mathrm{C}, 2 \mathrm{~h}$; (b) $\mathrm{PhCOCl}$ or $\mathrm{ClP}(=\mathrm{O})(\mathrm{OEt})_{2}$, $\mathrm{Et}_{3} \mathrm{~N}, \mathrm{DCM}, 25^{\circ} \mathrm{C}, 3 \mathrm{~h}$.

The synthesized compounds $\mathbf{6 d}, 7 \mathbf{a}-\mathbf{e}, 8 \mathbf{d}, \mathbf{8 f}, 9, \mathbf{1 0 a}, 10 \mathrm{~b}$ having the 3-aminooxindole core were tested for their antiproliferative activity on five human tumor cell lines, the PC3 (prostatic adenocarcinoma), the MCF7 (breast adenocarcinoma), the SW620 (colorectal adenocarcinoma), the MiaPaca2 (pancreatic adenocarcinoma) and A375 (melanoma) cell lines at 50, 25, 12.5 and 6.25 $\mu \mathrm{M}$ (Figures S1-S5) concentrations and expressed as $\mathrm{IC}_{50}$ values (Table 1). Moreover, the toxicity of the compounds on PBMCs (Peripheral Blood Mononuclear Cells) from healthy donors was also tested at 100, 50, 25, 12.5 and $6.25 \mu \mathrm{M}$ concentrations and expressed as $\mathrm{IC}_{50}$ values (Table 1, Figure S6).

In a preliminary evaluation some of the tested compounds showed a detectable activity (Table 1). In particular, the most cytotoxic derivatives in all the considered tumor cell lines were compound 6d, characterized by a $\mathrm{N}=\mathrm{PPh}_{3}$ substituent linked to the $\mathrm{C}-3$ position and $\mathrm{H}$ in position 1 and compound 7d characterized by a NCO substituent linked to the C-3 position and $\mathrm{H}$ in position 1 (Scheme 1). They showed an $\mathrm{IC}_{50}$ on the low micromolar range of respectively 6-10 and 7-20 $\mu \mathrm{M}$ in all the considered cancer cell lines inducing a $100 \%$ of mortality at almost all the tested doses (Figures S1-S5).

Other compounds such as $\mathbf{7 a}, \mathbf{7 b}$ and $\mathbf{7 e}$ exhibited cytotoxic dose dependent effects only on prostatic cancer cell line PC3 (Figure S1) and 7a and 7b also on breast cancer cell line MCF7 (Figure S2) at an IC 50 lower than $50 \mu \mathrm{M}$ (Table 1). Compounds 8d, 8f, 9 and 10a exerted toxic effects on cancer cell lines (Figures S1S5) but only at high concentrations with an $\mathrm{IC}_{50}$ higher than $50 \mu \mathrm{M}$ (Table 1). Compound 10b showed an antitumoral efficacy in adenocarcinoma cancer cell SW620 and pancreatic cell line MiaPaca2 in a dose dependent manner (Figures S3, S4) and with an $\mathrm{IC}_{50}$ of respectively 28 and $30 \mu \mathrm{M}$ (Table 1). 
Table 1. Cell growth inhibition in the presence of examined compounds

$$
\mathrm{IC}_{50}(\mu \mathrm{M})^{\mathrm{a}}
$$

\begin{tabular}{lllllll} 
Cmpd & PC3 & MCF7 & SW620 & MiaPaca2 & A375 & PBMC \\
\hline 6d & 8.63 & $<6.25$ & $<6.25$ & $<6.25$ & 9.04 & 30.71 \\
$\mathbf{7 a}$ & 18.20 & 14.38 & $>50$ & 47.01 & $>50$ & 45.52 \\
$\mathbf{7 b}$ & 17.04 & 30.44 & $>50$ & $>50$ & $>50$ & $>100$ \\
$\mathbf{7 d}$ & 8.95 & 17.68 & 9.81 & 7.46 & 6.41 & 75.30 \\
$\mathbf{7 e}$ & 32.51 & $>50$ & $>50$ & $>50$ & $>50$ & $>100$ \\
$\mathbf{8 d}$ & $>50$ & $>50$ & $>50$ & $>50$ & $>50$ & $>100$ \\
$\mathbf{8 f}$ & $>50$ & $>50$ & 37.05 & 43.09 & $>50$ & $>100$ \\
$\mathbf{9}$ & N.D. & $>50$ & $>50$ & N.D. $^{\mathrm{b}}$ & $>50$ & $>100$ \\
$\mathbf{1 0 a}$ & $>50$ & $>50$ & $>50$ & $>50$ & $>50$ & $>100$ \\
$\mathbf{1 0 b}$ & $>50$ & $>50$ & 27.70 & 30.21 & $>50$ & 51.78 \\
\hline
\end{tabular}

${ }^{a}$ Values of at least two independent experiments.

${ }^{\mathrm{b}}$ N.D. $=$ Not Determined.

The evaluation test on the toxicity in the primary cells PBMC showed that among the compounds that exerted an antitumor activity, compound $\mathbf{6 d}$ showed an $\mathrm{IC}_{50}$ of $30.71 \mu \mathrm{M}$ but with an anticancer activity at doses lower than $6.25 \mu \mathrm{M}$ (Table 1). Compound 7d showed an $\mathrm{IC}_{50}$ on PBMCs higher than $50 \mu \mathrm{M}$ and compound 7a showed an $\mathrm{IC}_{50}$ of $45.5 \mu \mathrm{M}$ (Table 1).

In the present work, we have evaluated the potential anti-tumor effects of several compounds on a panel of stabilized human cancer cell lines. Among the compounds tested, ten of them exerted anti-cancer activity, although at high concentrations (in the $\mu \mathrm{M}$ range) and not in all the tested cell lines. However, when evaluating the toxicity in primary cells, we observed that none of the compounds was toxic at the concentrations effective on cancer cells.

The most promising compounds that we believe deserve further testing are the $7 \mathbf{d}$ and $\mathbf{6 d}$. The first compound exhibits an important anti-cancer effect with toxicity in PBMCs at the dose of 50 and $100 \mu \mathrm{M}$. Compound 6d showed to be toxic on PBMCs cells already at the dose of $25 \mu \mathrm{M}$ but it showed a strong anticancer effect at doses lower than $6.25 \mu \mathrm{M}$.

These two compounds exhibit the same structure excepted for the group in C-3 respectively a triphenyliminophosphorane group in $\mathbf{6 d}$ and an isocyanate group in $\mathbf{7 d}$. The reduced activity of the compounds $7 \mathbf{a}, \mathbf{7 b}$ and $\mathbf{7 e}$ could be probably due to the presence of the acetyl group and the ethyl carboxylate group in position 1. Further structural and biological studies followed by SAR study are warrant for the better identification of the compounds with the highest anticancer activities.

It will be also important from a translation point of view, to assess the efficacy of the most promising compounds on primary cancer cells, and to shed light on their mechanisms of action, via the identification of putative receptors and modulation of intracellular signaling pathways. 


\section{Acknowledgments}

Università degli Studi di Milano is acknowledged for financial support ("Piano di Sostegno alla Ricerca" Linea 2).

\section{References and notes}

1. Lin, H.; Danishefsky, S. J. Angew. Chem. Int. Ed. 2003, 42, 36-51.

2. $\quad$ Marti, C.; Carreira, Erick M. Eur. J. Org. Chem. 2003, 2003, 2209-2219.

3. Singh, G. S.; Desta, Z. Y. Chem. Rev. 2012, 112, 6104-6155.

Song, Z.; Chen, C.-P.; Liu, J.; Wen, X.; Sun, H.; Yuan, H. Eur. J. Med. Chem. 2016, 124, 809-819.

Cao, Z.-Y.; Zhou, F.; Zhou, J. Acc. Chem. Res. 2018, 51, 1443-1454.

Cui, C.-B.; Kakeya, H.; Osada, H. Tetrahedron 1996, 52, 12651-12666.

Galliford, C. V.; Scheidt, K. A. Angew. Chem. Int. Ed. 2007, 46, 8748-8758.

Zhao, Y.; Yu, S.; Sun, W.; Liu, L.; Lu, J.; McEachern, D.; Shargary, S.; Bernard, D.; Li, X.; Zhao, T.; Zou, P.; Sun, D.; Wang, S. J. Med. Chem. 2013, 56, 5553-5561.

9. $\quad$ Yu, B.; Yu, D.-Q.; Liu, H.-M. Eur. J. Med. Chem. 2015, 97, 673-698.

10. Teng, D. Z., Hongxing; Mendonca, A. . Molecules 2006, 11, 700-706.

11. Zhou, F.; Liu, Y.-L.; Zhou, J. Adv. Synth. Catal. 2010, 352, 1381-1407.

12. Klein, J. E. M. N.; Taylor, R. J. K. Eur. J. Org. Chem. 2011, 2011, 6821-6841.

13. Hong, L.; Wang, R. Adv. Synth. Catal. 2013, 355, 1023-1052.

14. Moyano, A. C., X. Elsevier Ed., 2013; pp. 71-132.

15. Tak, R. K.; Gupta, N.; Kumar, M.; Kureshy, R. I.; Khan, N.-u. H.; Suresh, E. Eur. J. Org. Chem. 2018, $2018,5678-$ 5687.

16. Sato, S.; Shibuya, M.; Kanoh, N.; Iwabuchi, Y. J. Org. Chem. 2009, 74, 7522-7524

17. Tokunaga, T.; Hume, W. E.; Umezome, T.; Okazaki, K.; Ueki, Y.; Kumagai, K.; Hourai, S.; Nagamine, J.; Seki, H.; Taiji, M.; Noguchi, H.; Nagata, R. J. Med. Chem. 2001, 44, 4641-4649.

18. Bernard, K.; Bogliolo, S.; Ehrenfeld, J. British Journal of Pharmacology 2005, 144, 1037-1050.

19. Shimazaki, T.; Iijima, M.; Chaki, S. European Journal of Pharmacology 2006, 543, 63-67.

20. Decaux, G.; Soupart, A.; Vassart, G. The Lancet 2008, 371, 1624-1632.

21. Ghosh, A. K.; Schiltz, G.; Perali, R. S.; Leshchenko, S.; Kay, S.; Walters, D. E.; Koh, Y.; Maeda, K.; Mitsuya, H. Bioorg. Med. Chem. Lett. 2006, 16, 1869-1873.

22. Shanmugam, P.; Viswambharan, B.; Madhavan, S. Org. Lett. 2007, 9, 4095-4098.

23. Kouznetsov, V. V.; Bello Forero, J. S.; Amado Torres, D. F. Tetrahedron Lett. 2008, 49, 5855-5857.

24.

25. Rainoldi, G.; Lesma, G.; Picozzi, C.; Lo Presti, L.; Silvani, A. RSC Advances 2018, 8, 34903-34910. Bui, T.; Borregan, M.; Barbas, C. F. J. Org. Chem. 2009, 74, 8935-8938.

Cheng, L.; Liu, L.; Wang, D.; Chen, Y.-J. Org. Lett. 2009, 11, 3874-3877.

Lesma, G.; Landoni, N.; Pilati, T.; Sacchetti, A.; Silvani, A. J. Org. Chem. 2009, 74, 4537-4541.

Qian, Z.-Q.; Zhou, F.; Du, T.-P.; Wang, B.-L.; Ding, M.; Zhao, X.-L.; Zhou, J. Chem. Commun. 2009, 6753-6755.

Bui, T.; Hernández-Torres, G.; Milite, C.; Barbas, C. F. Org. Lett. 2010, 12, 5696-5699.

Mouri, S.; Chen, Z.; Mitsunuma, H.; Furutachi, M.; Matsunaga, S.; Shibasaki, M. J. Am. Chem. Soc. 2010, 132, 12551257.

31. Yang, Z.; Wang, Z.; Bai, S.; Shen, K.; Chen, D.; Liu, X.; Lin, L.; Feng, X. Chem. Eur. J. 2010, $16,6632-6637$.

32. Beccalli, E. M.; Clerici, F.; Marchesini, A. Tetrahedron 2001, 57, 4787-4792.

33. Beccalli, E. M.; Clerici, F.; Gelmi, M. L. Tetrahedron 2003, 59, 4615-4622.

34. Christodoulou, M. S.; Giofrè, S.; Broggini, G.; Dalla Via, L.; Mazza, A.; Beccalli, E. M. ChemistrySelect 2018, 3, 43614365.

35. Beccalli, E. M.; Bernasconi, A.; Borsini, E.; Broggini, G.; Rigamonti, M.; Zecchi, G. J. Org. Chem. 2010, 75, 69236932.

36. Broggini, G.; Barbera, V.; Beccalli, E. M.; Chiacchio, U.; Fasana, A.; Galli, S.; Gazzola, S. Adv. Synth. Catal. 2013, 355, 1640-1648.

37. Beccalli, E. M.; Marchesini, A.; Pilati, T. Tetrahedron 1992, 48, 5359-5374.

38. Mazza, A.; Beccalli, E. M.; Contini, A.; Garcia-Argaez, A. N.; Dalla Via, L.; Gelmi, M. L. Eur. J. Med. Chem. 2016, 124, 326-339.

39. Christodoulou, M. S.; Zarate, M.; Ricci, F.; Damia, G.; Pieraccini, S.; Dapiaggi, F.; Sironi, M.; Lo Presti, L.; GarcíaArgáez, A. N.; Dalla Via, L.; Passarella, D. Eur. J. Med. Chem. 2016, 118, 79-89.

40. Gabriele, E.; Porta, F.; Facchetti, G.; Galli, C.; Gelain, A.; Meneghetti, F.; Rimoldi, I.; Romeo, S.; Villa, S.; Ricci, C.; Ferri, N.; Asai, A.; Barlocco, D.; Sparatore, A. Arkivoc 2017, part ii, 235-250.

41. Christodoulou, M. S.; Mori, M.; Pantano, R.; Alfonsi, R.; Infante, P.; Botta, M.; Damia, G.; Ricci, F.; Sotiropoulou, P. A.; Liekens, S.; Botta, B.; Passarella, D. ChemPlusChem 2015, 80, 938-943. 
42. Rimoldi, I.; Coccè, V.; Facchetti, G.; Alessandri, G.; Brini, A. T.; Sisto, F.; Parati, E.; Cavicchini, L.; Lucchini, G.; Petrella, F.; Ciusani, E.; Pessina, A. Biomed Pharmacother 2018, 108, 111-118.

43. Christodoulou, M. S.; Caporuscio, F.; Restelli, V.; Carlino, L.; Cannazza, G.; Costanzi, E.; Citti, C.; Lo Presti, L.; Pisani, P.; Battistutta, R.; Broggini, M.; Passarella, D.; Rastelli, G. ChemMedChem 2017, 12, 33-41.

44. Marucci, C.; Christodoulou, M. S.; Pieraccini, S.; Sironi, M.; Dapiaggi, F.; Cartelli, D.; Calogero, A. M.; Cappelletti, G.; Vilanova, C.; Gazzola, S.; Broggini, G.; Passarella, D. Eur. J. Org. Chem. 2016, 2016, 2029-2036.

45. Carlino, L.; Christodoulou, M. S.; Restelli, V.; Caporuscio, F.; Foschi, F.; Semrau, M. S.; Costanzi, E.; Tinivella, A.; Pinzi, L.; Lo Presti, L.; Battistutta, R.; Storici, P.; Broggini, M.; Passarella, D.; Rastelli, G. ChemMedChem 2018, 13, 2627-2634.

46. Quaglio, D.; Zhdanovskaya, N.; Tobajas, G.; Cuartas, V.; Balducci, S.; Christodoulou, M. S.; Fabrizi, G.; Gargantilla, M.; Priego, E.-M.; Carmona Pestaña, Á.; Passarella, D.; Screpanti, I.; Botta, B.; Palermo, R.; Mori, M.; Ghirga, F.; Pérez-Pérez, M.-J. ACS Med. Chem. Lett. 2019, 10, 639-643.

47. Facchetti, G.; Ferri, N.; Lupo, M. G.; Giorgio, L.; Rimoldi, I. Eur. J. Inorg. Chem. 2019, 2019, 3389-3395.

48. Ferri, N.; Radice, T.; Antonino, M.; Beccalli, E. M.; Tinelli, S.; Zunino, F.; Corsini, A.; Pratesi, G.; Ragg, E. M.; Gelmi, M. L.; Contini, A. Bioorg. Med. Chem. 2011, 19, 5291-5299.

49. Ferri, N.; Beccalli, E. M.; Contini, A.; Corsini, A.; Antonino, M.; Radice, T.; Pratesi, G.; Tinelli, S.; Zunino, F.; Gelmi, M. L. Bioorg. Med. Chem. 2008, 16, 1691-1701. 